\title{
Études/Inuit/Studies
}

\section{Greenlandic attitudes towards Norwegians and Danes from Nansen's icecap crossing to the 1933 World Court verdict in The Hague}

\section{Les attitudes groenlandaises envers les Norvégiens et les Danois, de la traversée de la calotte glacière par Nansen au jugement de 1933 de la Cour internationale à La Haye}

\section{Karen Langgård}

Volume 38, numéro 1-2, 2014

Cultures inuit, gouvernance et cosmopolitiques

Inuit cultures, governance and cosmopolitics

URI : https://id.erudit.org/iderudit/1028853ar

DOI : https://doi.org/10.7202/1028853ar

Aller au sommaire du numéro

Éditeur(s)

Association Inuksiutiit Katimajiit Inc.

Centre interuniversitaire d'études et de recherches autochtones (CIÉRA)

ISSN

0701-1008 (imprimé)

1708-5268 (numérique)

Découvrir la revue

Citer cet article

Langgård, K. (2014). Greenlandic attitudes towards Norwegians and Danes from Nansen's icecap crossing to the 1933 World Court verdict in The Hague. Études/Inuit/Studies, 38(1-2), 53-71. https://doi.org/10.7202/1028853ar

\section{Résumé de l'article}

Fridtjof Nansen (1861-1930), après avoir traversé la calotte glaciaire du Groenland, a passé l'hiver à Nuuk et a impressionné les Groenlandais par sa compétence et son audace en kayak, mais aussi par son ouverture d'esprit vis-à-vis de la nourriture, la culture et les traditions groenlandaises. Plus tard, lorsque les Danois et les Norvégiens sont entrés en conflit au sujet du Groenland, les Groenlandais ont soutenu la puissance coloniale danoise contre la Norvège, tout en reprochant aux Danois de ne pas avoir montré assez de respect envers les Groenlandais durant ledit processus. Les articles des journaux nationaux groenlandais Atuagagdliutit et Avangnâmiok démontrent que les Groenlandais étaient ouverts d'esprit envers les Norvégiens mais critiques envers les Danois. Tout en apportant leur soutien à ces derniers comme puissance coloniale contre la Norvège, les Groenlandais n'ont toutefois jamais oublié l'idée de l'intégrité ethnique et nationale du Groenland, même si, à ce moment-là, le pays était encore colonisé par les Danois. L'auteure conclut que l'agentivité groenlandaise que l'on découvre dans ces articles est très pertinente dans l'analyse du discours contemporain sur les Groenlandais de la période coloniale. 


\title{
Greenlandic attitudes towards Norwegians and Danes from Nansen's icecap crossing to the 1933 World Court verdict in The Hague
}

\author{
Karen Langgård*
}

Résumé: Les attitudes groenlandaises envers les Norvégiens et les Danois, de la traversée de la calotte glacière par Nansen au jugement de 1933 de la Cour internationale à La Haye

Fridtjof Nansen (1861-1930), après avoir traversé la calotte glaciaire du Groenland, a passé l'hiver à Nuuk et a impressionné les Groenlandais par sa compétence et son audace en kayak, mais aussi par son ouverture d'esprit vis-à-vis de la nourriture, la culture et les traditions groenlandaises. Plus tard, lorsque les Danois et les Norvégiens sont entrés en conflit au sujet du Groenland, les Groenlandais ont soutenu la puissance coloniale danoise contre la Norvège, tout en reprochant aux Danois de ne pas avoir montré assez de respect envers les Groenlandais durant ledit processus. Les articles des journaux nationaux groenlandais Atuagagdliutit et Avangnâmiok démontrent que les Groenlandais étaient ouverts d'esprit envers les Norvégiens mais critiques envers les Danois. Tout en apportant leur soutien à ces derniers comme puissance coloniale contre la Norvège, les Groenlandais n'ont toutefois jamais oublié l'idée de l'intégrité ethnique et nationale du Groenland, même si, à ce moment-là, le pays était encore colonisé par les Danois. L'auteure conclut que l'agentivité groenlandaise que l'on découvre dans ces articles est très pertinente dans l'analyse du discours contemporain sur les Groenlandais de la période coloniale.

Abstract: Greenlandic attitudes towards Norwegians and Danes from Nansen's icecap crossing to the 1933 World Court verdict in The Hague

After Fridtjof Nansen (1861-1930) crossed the Greenland icecap, he spent the winter in Nuuk and impressed the Greenlanders not only by demonstrating his skill and daring in kayaking, but also by his openness to Greenlandic food, culture, and traditions. Later on, when Danes and Norwegians came into conflict over Greenland, Greenlanders supported the Danish colonial power against Norway, while at the same criticizing the Danes for not paying enough respect to Greenlanders during the process. Articles from the national Greenlandic newspapers Atuagagdliutit and Avangnâmiok demonstrate that Greenlanders were open-minded towards Norwegians but critical towards Danes. They fully supported the latter as a colonial power against Norway, while never refraining from the idea that Greenland remained their ethnicnational territory, even though for the time being it was colonized by the Danes. The author concludes that Greenlandic agency found in these newspapers is very relevant when negotiating today's discourse on colonial Greenlanders.

\footnotetext{
* Department of Greenlandic Language, Literature and Media, Ilisimatusarfik / University of Greenland, P.O. Box 279, GR-3900 Nuuk, Greenland. kala@slm.uni.gl
} 


\section{Introduction}

The Norse population of West Greenland became subservient to the Norwegian king during the Middle Ages. After the Norse era came to a close, this connection was lost for a long time. In 1721, Greenland was again colonized by the twin kingdoms of Denmark and Norway, the driving force being the Norwegian missionary Hans Egede, whom the Danish king had sent to Greenland. During the Napoleonic Wars Denmark lost Norway but kept Greenland. Until the period of mobilization for Home Rule, no one criticized the efforts by Hans Egede and his two sons. Greenlanders appear to have thought that the Egedes did right. This belief was mirrored in the Greenlandic newspaper established in 1861 and in the monuments raised in honour of Hans Egede. The West Greenlandic population of the 19th century was Christian by convictionsecularization started much later than in Northern Europe. Only with the process of mental decolonization around 1979 did Greenlanders utter critical words (e.g., in poetry) that portrayed Egede as symbolizing colonialism and cultural destruction of authentic Inuit spirituality. Further, his statue in Nuuk was vandalized with paint in the late 1970s, and again in May 2012, actions not approved of, however, by the general population of Nuuk.

How did relations with the Norwegians evolve? In the late 1880s Fridtjof Nansen crossed the Greenland icecap from East Greenland and stayed in Nuuk for a winter. What did Greenlanders in the Nuuk district think of Nansen? How about other Norwegians on expeditions to Greenland and the Arctic? Around 1,900 Norwegians hunted seals on the sea ice off the East Greenland coast and whales in the sea off West Greenland. What were the Greenlandic reactions to their presence?

The Danish colonial government was based on a division of West Greenland into northern and southern portions. The Danes established a trade station and mission in Angmagssalik in East Greenland in 1894. Knud Rasmussen and Peter Freuchen established trade and a mission in the Thule area in 1910. Except for an upstart pastor in East Greenland, West Greenlandic pastors and catechists did the mission work. West Greenlanders saw this task as an important one and took ethnic-national pride in it. Thus the process of including the Thule area and East Greenland began more explicitly around 1900, transforming them into a part of the ethnic-national "imagined community" (Anderson 1983): Kalaallit Nunaat (Greenland), also named Nunarput ('Our Land') (Langgård 2010). ${ }^{1}$

West Greenlanders were informed by the Greenlandic newspaper Atuagagdliutit, and from 1913 also by Avangnâmiok, ${ }^{2}$ about Norwegian activities in East Greenland,

1 All Greenlandic words are rendered according to the orthography of 1973, and translated by me.

2 Atuagagdliutit was founded by H.J. Rink, the South Greenland governor. It had a Greenlandic editor, was written solely in Kalaallisut and was meant for West Greenlanders. It was distributed in both South and North Greenland. The newspaper had 200 pages per year and was published in 12 issues. Though distributed in the North and publishing articles sent in by North Greenlandic readers, it was dominated by South Greenlanders. North Greenlanders still wanted a newspaper based in North Greenland, and in 
about the political negotiations between Denmark and Norway, about the resulting disputes, and about their outcomes. Using articles published in the Greenlandic newspapers, I will explore what Greenlanders got out of this information and how they responded to the Norwegian demands. I will also discuss how they responded to decisions that the Danish State made during negotiations without consulting the two West Greenlandic Landsrådit (provincial assemblies, one for North Greenland and one for South Greenland, established by a 1908 law). ${ }^{3}$

A recurrent theme of this article will be the West Greenlanders' role as seen through contemporary Greenlandic media. Were West Greenlanders passive or did they exercise agency? And if they exercised agency, how did they do it? How did Greenlanders respond? No doubt at all, the South Greenland governor would have been informed about the contents of Atuagagdliutit, and the North Greenland governor similarly informed about Avangnâmiok. The colonial power created the framework of this asymmetrical power relationship, but what happened among Greenlanders in the space within this framework? What was written in the newspapers? Finally, I will also suggest that this kind of research has relevance to current political issues.

\section{Greenlanders' attitudes towards Nansen}

From its first issue in 1861, Atuagagdliutit brought news and informative articles about the world and Greenland, including discussions, translations of foreign literature, and many illustrations. Readers were supposed to send in articles about exciting experiences from their lives and about how to solve socio-political problems at a time when Greenlanders were increasingly engaged in a nation-building project and forming their ethnic-national identity. By 1900, this project was incorporating more and more Inuit from East Greenland and the Thule area.

Atuagagdliutit published many travel accounts from the Arctic, especially Greenland, and from elsewhere in the world (e.g., the voyages of Livingstone and Stanley in Africa). Greenlanders would send in articles about their own travel and hunting experiences. Of special interest were articles about expeditions that included Greenlandic participants. Of these, the most spectacular were the expeditions to the Thule area, the ones further west to the North Pole that included Hans Hendrik (18341889), and the Women's Boat Expedition to East Greenland in which Hanseeraq took part (Langgård 2010). Readers were proud of participation by Greenlanders in such expeditions and avidly read articles about them. Although foreign reports were enjoyed, the most prized articles were those that included Greenlanders and had been written by Greenlanders.

1913 Avangnâmiok was founded using the same format as Atuagagdliutit. Newspaper coverage in Greenland thus became more balanced (Langgård 1998, 2011a, b). 
Fridtjof Nansen (1861-1930) crossed the icecap in the late 1880s from East to West. The Greenlandic newspaper Atuagagdliutit covered the event by letting Nansen himself recount his crossing. But Nansen's narration was taken over by a Greenlander, Siilarsi, who told how he had been asked to interrupt his hunting and find Nansen after the expedition had descended from the icecap in the vicinity of Nuuk. From a 2013 standpoint, the breaking news should have been that the icecap had been crossed; further, the order of narration should more logically have been chronological. Not so in Atuagagdliutit. The same issue ran the first half of Nansen's report, leaving him and his team on the sea off East Greenland, and the first part of Siilarsi's report. The last parts of both reports were continued in the next issue (Nansen 1888-1889; Siilarsi 18881889). The local report was thus considered as important as the "foreigner's" report.

Further, Siilarsi described how he had been hunting and was not at all very keen on leaving that task to pick up Nansen and his men. He told the readers how he and the Greenlander sent with him found out that other Greenlanders had already met Nansen; he himself insisted on going with them to Nuuk in order to earn a higher wage, even though the Europeans had ordered him to go back to his hunting. As with other reports of this kind, Siilarsi's own purchase of a gun and his return home takes up much of the article. In no way do we meet a humble, colonial Greenlandic voice in Siilarsi's report.

Siilarsi's report focuses less on Nansen than on the two Saami accompanying Nansen. He stated that he looked forward to seeing the Saami. He had heard about them, but not much about how they looked. On meeting them he was surprised by their clothes and the differences in dress between them and the Europeans-and he went on to describe them. While not considering the Saami to be "real" Europeans, he did see them as a kind of European. ${ }^{4}$ When asked to slip into a sleeping bag next to the older of the Saami, Siilarsi's companion refused although Siilarsi obeyed, but with disgust. Thus, once more, he experienced the Saami as Europeans. His explanation for his disgust was that he had never slept this way with a European. The next day Siilarsi got some reindeer and all joined in the meal happily together. The first part of Siilarsi's article was followed by a song written for the occasion by the young Christian Rosing (1888-1889), who later in 1904 became the first Greenlandic pastor in East Greenland. The song's focus was on the expedition and even more so on the Saami.

The Atuagagdliutit editor, Lars Møller, had to postpone printing illustrations of Nansen's expedition gear to the next volume, where he included Nansen's picture and the promised article about $i k k u$ sapiitsorsuit ('those extraordinarily brave and skilful ones') (Møller 1889-1890). The editor described how Nansen learned to use a kayak, became proficient, and went hunting in one. One November day, he followed the local kayakers across the Nuuk Fjord and beyond. When the others had returned in the evening, he was still out there in rather bad weather and a stiff breeze. The Greenlanders were on the verge of going to look for him in an umiaq ('women's boat')

4 Although he focused on the Saami, the title of his article is Qallunaat (i.e. Danes or Europeans-white people). Thus, those who had crossed the icecap were white men even though some of them were Saami. 
when he finally arrived. He had been chasing a dolphin without success, but despite the dark and the wind he had no trouble finding his way home with his compass. Møller went on to tell how sometimes Nansen went around with his fellow Norwegian countrymen, or stayed alone with Greenlanders in their settlements to hunt and fish with them. Møller was much impressed by Nansen's skill and his ability to return home unharmed even in bad weather: "qallunaarsuulluni kalaalipalaasugut saperseqimmatigut" ('He, a big European, outdoes us poor Greenlanders very much') (ibid.: 3). Some of the other Norwegians and the younger Saami, Balto, also impressed the Greenlanders by their willingness to go kayaking (ibid.: 5).

This focus on Nansen's prowess in fishing and hunting from a kayak should be seen in context. First, in colonial Greenland only a few Europeans went kayaking, and kayak hunting was central to the developing Greenlandic ethnic-national identity of this period. Second, by the mid-19th century, Greenlandic seal hunting ${ }^{5}$ was in a crisis that would abate only with the beginning of a large-scale fishery in the early 20th century. The seal crisis was a major reason why Governor H.J. Rink founded Atuagagdliutit and the theme of many articles during the last four decades of the 19th century. Thus, when the newspaper editor praised Nansen for his kayak hunting, the praise was neither superficial nor unimportant. It should be seen as a real homage to Nansen.

Møller added that Nansen and his team ate local food and that Nansen learnt Greenlandic. Møller told his readers about Nansen and his fellow travellers skiing, including a picture of all expedition members and their skiing gear. Once more he extolled Nansen for ascending the ice foot without taking off his skis. Møller also recounted how the older Saami, Ravna, told him about his way of life and his reindeer, and how both of the Saami explained that it would be fine to herd reindeer in Ameralik Fjord southeast of Nuuk. He ended his article by referring to the thanks sent by Nansen and his expedition from Norway: "Nunatsinni angalasartorpassuarni aatsaat nunarput qimareerlugu maanimiunut qujasoqarpoq, maani ilassineqarluarnertik paaqqilluarneqarnertillu pillugu" ("Although there are lots of travellers coming all the time to our country, this is the very first time that somebody after leaving our country has thanked those living here, for having been warmly welcomed and well treated here') (ibid.: 188).

Hammeken, a trade manager, also mentioned Nansen's other experiences in a very long article of his published in several issues of Atuagagdliutit during 1889-1890. He added a description of Nansen kayaking in Kangeq, a settlement in the Nuuk area, describing how he himself had kayaked with Nansen, impressed but also alarmed by his daring. Hammeken also remembered Nansen and how he, while staying in Kangeq, visited the biggest of the huts and how he enjoyed being offered seal meat on his return from hunting (Hammeken 1889-1890: 152, 162-163).

5 A seal hunter, piniartoq, would mainly hunt seals and a lot of other species, including some fish species. The proportions varied by locality and season. 
Nansen left behind a feeling that he really had enjoyed the Greenlandic way of life and the Greenlanders. Nansen was mentioned time and again over the years. Other Arctic (and Antarctic) expedition leaders were depicted rather often, together with other international news items under a recurrent heading on the last page of each issue. In 1907, quite a few pages were devoted to Roald Amundsen as he made his way to the North Pole, and to Cook in 1909.

\section{Nansen's attitude to Norwegian seal hunting along the East Greenland coast and Greenlandic reactions}

In 1888, a Greenlandic seal hunter wrote in Atuagagdliutit that the presence of American fishing ships had caused the halibut to disappear. He was thus aware that foreign overfishing could endanger local fish stocks near the West Greenland coast (Joab 1887-1888: 144). In the next volume, Nansen inserted a long passage into his article about Norwegian sealing on the polar ice drifting southwards along the East Greenland coast. He described how Norwegian sealing methods and goals differed greatly from Greenlandic ones, and stressed that Norwegian methods on such a scale would harm seal stocks and thus Greenlanders (Nansen 1888-1889: 147-150). He found it very sad to observe that all the seal meat from the Norwegian hunt was left to rot; he stated the enormous figures and went on to state: "Taama natsersuarniartarneq natsersuarnut ajoqutaassaqisoq nalunangaanngilaq, ukiullu qassiit taamatut ukiumit 1876-mit aallarnerlutik Danmarkip ikerasaani piniartaannarpatigik, siooragaara Kalaallit tunumiut ajorsartalissasut natsersuit nungukkiartornerat patsisigalugu" ('It is quite obvious that such hunting of hooded seals does much harm, and if they, starting with the year 1876, will go on and on hunting like this in the Denmark Strait, I fear that the East Greenlanders will suffer hardships because of the decrease in the seal stocks') (ibid.: 149). He stated that the Norwegians might be pulling out because the catch was already decimated and no longer profitable. Thus, Atuagagdliutit published not only the glamorous side to the European and American presence off Greenland's shores, but the conflictual side as well.

In 1890, Atuagagdliutit published a list of Norwegian seal catch totals, not including sealing by other nationalities. There followed a comment that the totals were considerable, although Greenlanders were also catching 50,000 to 70,000 per year. The contributor to the newspaper-no doubt the editor himself-concluded with the following remark: "Tassa umiarsuit 19 katillugit 45.880 pisarisimagaat, (angisuut 9.050, piaqqat 36.830.) Tamakkorpassuilli amiinnaat orsuinnaallu pisarpaat, neqaat sussarinnginnamikkik igittarpaat, massa uagut kalaaliusugut neqaat piumangaarlugillu qujassutigingaassagaluarivut" ("This means that 19 ships have caught 45,880 [9,050 adults, 36,830 cubs]. But all they take from all these is the skins and the blubber; they throw away the meat because they don't care about it, while we Greenlanders would very much like it and would have been very happy to get it')" (Anonymous 1890-1891: 95-96). The comment emphasized Norwegian wastefulness. 
Drawing on Danish newspapers and magazines, the Atuagagdliutit editor presented his readers with news about the successful establishment of trade and creation of a mission in Angmagssalik in 1894, and informed them that Norwegian ships had traded with the East Greenlanders the year before (Møller 1895-1896: 52-53). The latter news item was seen as very bad because Greenland had been closed to foreigners in order to protect Danish trade from competition and the Greenlandic population from diseases. From then on articles originally written for Danish newspapers were published in Greenlandic in Atuagagdliutit and, a little later, articles by Greenlandic catechists stationed in East Greenland were included. The newspaper often ran items about marine resources off East Greenland and West Greenland, as well as similar dispatches from Danish and other European sources.

After 1900, the horizon widened to encompass news about catches off St. John's, Newfoundland in the short notices at the end of Atuagagdliutit. The Greenland seal was said to be harvested unsustainably off St. John's (e.g., Anonymous 1901-1902: 32, 1906-1907: 31-32). The aim was thus to inform Greenlandic readers, rather globallywith news from all continents, but in a totally unsystematic way. Over the years, the newspaper was enlivened with illustrations, some of which were connected to the articles, but most not. There was still criticism of foreigners hunting seals off East Greenland's shores (e.g., Storch 1911-1912: 180).

\section{Greenlandic newspaper articles 1920-1933 about Norway}

I will now jump to the 1920s and consider how the Greenlandic media responded to the gradually worsening relations between Denmark and Norway over East Greenland, and a little later over the whole of Greenland, in a dispute that ended with a World Court verdict in The Hague in 1933. In the decades before 1900, socio-political issues in Greenlandic newspaper articles were largely confined to criticisms of hunters for not doing enough kayaking, seal hunting, and thus providing for their families and communities. In the second decade of the 20th century, introduction of the so-called "rational" fishery together with other new trends triggered a vehement and skilful negotiation of Greenlandic ethnic-national identity. In the 1920s, the prominent challenge was how to ensure that everyone participated in socio-political progress towards a better life. In this arena a lot of issues were included, from the prices that Greenlandic hunters earned for their catches to the general feeling that renewable resources were limited. The latter issue was part of discussion about nation-wide preservation of game, about Greenlanders' reactions to foreigners hunting and fishing at sea off Greenland's shores, and about their presence on land at certain places.

\section{The new Atuagagdliutit editor}

In 1922, Lars Møller retired after a long life of editing Atuagagdliutit since 1861, first as an assistant to the first editor, Rasmus Berthelsen, and then, after 12 years, as editor for five decades. His successor was a young, ambitious man, Kristoffer Lynge, 
who displayed no reverence for his predecessor when he started, but promised instead to change the newspaper a lot. During his first few years he showed off rather impudently his own knowledge whenever he found that the other contributors' articles displayed less knowledge than his own. The discussions among readers became less vivid than before he took over. Once he had taken over, many articles were amended by the know-it-all editor and very few wrote back to protest his "corrections." How much he really was directly serving the interests of his employer, the Danish colonizer, is an interesting question.

There was another and much more positive innovation. The young editor wrote more systematically on foreign affairs, in Denmark and in the rest of the world. Earlier, in 1864, Atuagagdliutit had covered Denmark's war with Prussia and subsequent defeat. Later, the First World War had been extensively depicted in both Atuagagdliutit and Avangnâmiok through texts, drawings, and photos of the campaigns and social impacts. Greenlandic readers were now much more up-to-date about what was going on outside Greenland. The deteriorating relations with Norway became increasingly topical in the columns on foreign affairs.

\section{The terms Nunarput and Kalaallit Nunaat in Greenlandic discourse}

Over the years Norwegians were mentioned for their Arctic and Antarctic expeditions. They were also newsworthy when Greenlanders discussed large-scale sealing off East Greenland's shores and its adverse consequences for the seal hunt on the West Greenland coast (e.g., Storch 1911-1912: 180). In the early 1920s the bigger states had already recognized Denmark's claim to the whole of Greenland. When Denmark asked Sweden and Norway for explicit recognition, Norway refused. Greenlandic readers were informed of this refusal by Lynge in the issues of Atuagagdliutit from 1922 to 1923, the same year he became editor. As examples of contemporary discourse I will quote two passages from his article. The first one is as follows: tassagooq qangarsuarli Norgemiut nunatta tunuanut uumasunik imarmiutanik nunamiutanillu piniariartartutoqaagamik tamanna attatiinnarumagamikku ('because, they [the Norwegians] said, since Norwegians long since had hunted sea mammals as well as land mammals at our country's backside, they wanted to go on with this')" (Lynge 1922-1923a: 52). The author used the phrase nunatta tunuanut ('our country's backside'), which is the West Greenlandic expression for East Greenland. The second passage goes as follows: “- Soorlikiarmi Danmarkip kalaallit nunaat tamaat pigilerpagu kikkulluunnit danskiunngitsut Dammarkimi naalakkersuisunit akuerineqartinnatik nunatsinnut piniariartussaassanngillat ('and why this-well, if Denmark gets the whole of Greenland anyone who is not Danish cannot go hunting in our country without permission from the Danish government')" (ibid.: 52).

"Greenland" in Kalaallisut is: Kalaallit Nunaat ('land of the Greenlanders'). "In our country" or rather "to our country" in Kalaallisut is Nunatsinnut, i.e. Nunarput ('our country') in the allative case. There is a pattern in these informative passages. When stating Norway's demands, the author referred to Greenland by the neutral term 
Kalaallit Nunaat. When then explaining the dispute to his readers, he adopted a Greenlandic perspective and used the common expression for the ethnic-national territory in daily discourse: Nunarput, as had been the practice from the very first issue of Atuagagdliutit in 1861 (Langgård 1998). The overall attitude was that two Scandinavian states were fighting over "our country," i.e. there is a country that is "ours," and this is not up for discussion. If anything is to be discussed, it will be which state should be the colonial power. Whatever the outcome of the dispute, the basic ownership of the country will not change in the eyes of Greenlanders. Further, description of East Greenland as the country's "backside" showed who had so far been writing Greenland's history: West Greenlanders. They were the first ones to turn their ethnic awareness into ethnic-national awareness (Langgård 2010).

Lynge's article drew on the Danish press to show how the Norwegians wanted to assert their rights. For example, in order to get 20 muskox calves to sell to European zoos, they must have slaughtered-according to knowledgeable Danish hunters-at least 200 full-grown muskoxen, which were shedding at the time and thus of no use, a terrible waste. Their explicit aim was to make a large profit. The unspoken message: this hunt was going on in just the same, unsustainable way as when the Norwegians were sealing offshore. They were exploiting the country without giving anything back to its owners, the Greenlanders (Lynge 1922-1923a: 53).

Both Atuagagdliutit and Avangnâmiok reported developments through the years in Norway's claim to East Greenland. Ethnic-national discourse-with expressions like the above quoted ones-was already in use when Atuagagdliutit started in 1861. During the next six decades, Greenlanders discussed socio-political and ethnic-national matters in the newspaper, including attitudes towards the Danes. In the 1920s, for the first time, they debated Greenland as the subject of an international dispute. The Atuagagdliutit editor and everybody else writing about this issue held to an ethnicnational discourse in their descriptions of Europeans fighting for the role of Greenland's colonial power. Although Greenlanders never renounced ownership of their own country, this position did not mean a refusal to recognize Denmark as the colonial power.

\section{The whaling issue and the Norwegians}

Norwegians were also mentioned in Greenlandic newspapers for their whaling beyond West Greenland waters, which was a difficult issue. Greenland was closed to foreigners, and thus Norwegians were not permitted to meet Greenlanders, but they disobeyed this rule. Greenlanders got some whale corpses from Norwegian whalers, sometimes to their benefit, but sometimes the corpses were putrefied and caused deaths. ${ }^{6}$ Thus, the situation was a mix of benefits and costs when the dispute between

$6 \quad$ E.g., 11 people died in 1925 (Tobiassen 1925-1926) in Kangeq. The description is followed by a warning about how much fish the Norwegians were harvesting beyond the reach of Greenlanders. The author spoke of aalisarfivut ('our fishing areas'), thus declaring ownership over the fish (ibid.: 37). 
Denmark and Norway over East Greenland appeared in the Greenlandic media in the early 1920 s.

In 1923, the whaling issue provoked a response from Kangaamiut, a settlement in the Maniitsoq district, in a text written for Atuagagdliutit by seal hunter Jakob Rosing (1922-1923). He stressed how Norwegians' unsustainable harvest not only failed to benefit the people of Greenland, but had also impoverished their country. Rosing also insisted that Greenlanders should diversify their economy. Seal hunting (including some fishing) and employment as catechists were simply not enough anymore at a time when all too many hunters were out of work. It was quite clear that the Norwegians were very interested in "our country," since they had even asked for a letter of gratitude from the Greenlanders (i.e. for the whale corpses). They were interested, even though Greenlanders were insufficiently prepared to open up their country and insufficiently educated. Then he mentioned how, before the First World War, the Landsrådit provincial assemblies wanted a whaling ship with a Greenlander crew. The war put the plan on hold, but it was now supposed to be implemented. Rosing also wrote that Greenlanders had to learn how to trade better and should focus on mining. This is a fine example of how Greenlanders were exercising agency, and it showed their flair for politics, such as using the Norwegian threat to ask for more investment in education and to acquire more whale meat and skins during the year.

Following Jakob Rosing's article, the new young editor Kristoffer Lynge wrote what he called naqqiut (corrections), where he more or less told Greenlanders to keep to their traditional livelihood of seal hunting-employing the same impudent tone as he did several times during his first few years as editor (Lynge 1922-1923b). First, this comment provoked a protest from the other newspaper, Avangnâmiok, which chided Lynge as an employee not to interfere with a debate among hunters (Reimer 1923). Then, Rosing himself replied that maybe the whaling ship should just be a small vessel and that he could see no reason why Greenlanders should not be taught how to handle such a ship! He went on arguing for his demands (Rosing 1923-1924). His article provoked an even less friendly response from the editor (Lynge 1923-1924). Actually, Rosing was not the only one asking for a ship. He was, however, the most strategically outspoken one. ${ }^{7}$

In the end, the small ship Sonja began to hunt for whales along the West Greenland coast from 1924, and from 1928 it delivered whale meat and skins to the communities along the coast, but with no Greenlanders aboard. Greenlanders were not empowered to reach their goals, but nonetheless exercised as much agency as they could. Although

7 E.g., the Avangnâmiok editor criticized the colonial authorities for rejecting a proposal for a whaling station and thus letting foreigners harvest what Greenlanders ought to have harvested. He exhorted Greenlanders to unite in order to change this state of affairs (Jensen 1920). A year later, a catechist claimed that a new boat bigger than a kayak was needed for hunting, like a ship. He stressed that had it not been for the Norwegians' whale meat and skins, the Greenlanders' dogs would have died during those years. This conclusion was almost as outspoken as Rosing's, although it was made before the East Greenland dispute (Kleist 1921). 
the newspapers show us the Greenlanders asking for an active role, this part of the story goes unmentioned in a school textbook's description of the ship Sonja (Aidt 2008).

\section{Greenlandic attitudes towards Norway and Denmark}

Ten years later at the World Court in The Hague, when Knud Rasmussen delivered his speech in favour of Denmark, he proclaimed that the Greenlanders supported Denmark (reported too in a 1933 issue of Avangnâmiok). However, this was not the whole truth. Some Greenlanders would have liked the Greenlandic population to live their lives independently of Denmark, but the best-educated Greenlanders argued that this end goal was not reachable yet because of the still too low educational level of Greenlanders in colonial Greenland. Hence, P. Rosing wrote that disdain for the Danes and utterances about how Qallunaat atorfeqanngitsut ("the Danes are of no use") were heard all too often, but reflected crass ignorance. He thought that Greenlanders and Danes had to collaborate more than ever (Rosing 1920).

Even though many contributors to the newspaper admonished collaboration, many of them would simultaneously criticize Danish colonial institutions for not doing enough, be it in education, in prices paid for Greenlandic products compared to in-store prices, or in listening to Greenlanders. A very outspoken example included a critique of the Danish administration's monopoly over purchasing of seal products and its setting of prices for seal hunters. It concluded that all in all this monopoly was keeping Greenlanders (i.e. seal hunters) away from independent trading and was the same as slavery (Egede 1926-1927). There was much criticism of the Danes. Yet none of the contributors thought that the Norwegians should replace the Danes as colonizers, nor did they quote other Greenlanders to that effect.

From 1920 to the 1933 World Court verdict in The Hague, the representatives in West Greenland's two advisory assemblies on the one hand criticized Danish authorities for their handling of Danish-Norwegian negotiations (the Greenlanders had not been consulted at the time), and on the other hand whole-heartedly supported Denmark against Norway's claims to Greenland. Denmark had in fact made a deal with Norway permitting Norwegians some (limited) hunting in East Greenland, without having consulted the Greenlanders beforehand.

In the minutes from the 1924 Northern Assembly, published as usual in Avangnamiok, the Greenlandic representatives argued that Norway's claims constituted a real threat, and they considered the situation dangerous. The Greenlanders thought that collaboration between Danes and Greenlanders was thus even more necessary. However, they felt that Denmark's behaviour was becoming a hindrance to collaboration (Lindow et al. 1924: 74-76). Thus, both critique and support were reported to newspaper readers.

Greenlanders became more and more self-confident. They wanted to be heard, and when they thought that the Danish authorities were not listening they would protest. All 
of the Landsrådit members of course knew that these political assemblies were purely advisory. Nevertheless, when Fr. Lynge, a member of the North Greenland Landsråd, found that the Greenlandic point of view was being ignored even though the members had in fact discussed some issues at great length, he wrote about the situation and finished his article with the question: "Soormi taava Landsraadet pisariaqanngitsumik oqaluusissinneqartassappat, oqaloqatigiissuteqarnermikkut piumasaat ataqqineqartassanngippat? Danmarkillu (pisortaasut) tungaanit Kalaallit Nunaata Landsrådii taamatut soqutigineqartassanngippata, kia taava kalaallit nammineq nunatsinniluunniit ataqqissavai? ("Why then should the assemblies be totally unnecessarily asked to discuss, when what they decided through discussion is not to be respected? And if Denmark (the Danish authorities) shows no interest in Greenland's assemblies, who then will respect the Greenlanders even in our country?')" (Lynge 1930: 74). The answer came from the governor, stating that they had only advisory power (Rosendahl 1930).

\section{Greenlandic responses to the dispute with Norway in the early 1930s}

In 1930, a West Greenlander wrote a long report in Avangnâmiok on how he and others patrolled the area north of Scoresbysund (the settlement established in the 1920s far to the north of Angmagssalik). The year was not specified. It is said that the report was planned as a separate publication, but when this project failed, it was published instead in the newspaper. Amid Greenlandic opposition to foreigners hunting in Greenland, he said that he was impressed by the toughness of the young Norwegians that he met and by their skill in hunting, especially muskoxen, but this admiration should not be understood as indicating feelings of inferiority, because after this tour, thanks to his own accomplishments, Greenlanders had no reason to be looked down upon as inferior (Gabrielsen 1930). The "significant others" were still the Danes. Furthermore, whatever the situation, when a Greenlander encountered a skilful hunter, he would pay due credit to him-the example here is in total accordance with the praise given Nansen's kayaking skills.

The international political ramifications of Danish-Norwegian disagreements over East Greenland were reported to Greenlandic readers through the newspapers, not least the events that happened at the World Court in The Hague, both when the court accepted the case and when the verdict was to be announced. All the resolutions from towns and assemblies in Greenland were mentioned too (P.N. 1932: 45; S.P. 1932: 5153). In 1927, the catechist in Kangaamiut wrote that the Norwegians' presence in Greenland and their country's goal to separate Greenland from Denmark made Greenlandic action necessary. Hans Egede was Norwegian, but his trip to Greenland had been made possible by assistance from the Danish king. If Greenland became free, very few (if any) Greenlanders would benefit. Greenlanders had to defend themselves by remaining Denmark's colony (Berthelsen 1927-1928).

The West Greenlandic literary author Pavia Petersen (1904-1943) also published several newspaper articles. The one entitled Kiinap ungalutoqarsua (The Great Wall of 
China) depicted how that wall meant stagnation for China and then went on to compare that situation to the one in Greenland, which was surrounded by its "wall," i.e. geographic isolation, lack of proficiency in foreign languages, lack of means to exploit the riches of the country, and lack of open-mindedness towards inspiration from abroad. Greenlanders were satisfied with Christianity and literacy, but with attainment of both goals, Europeans were thereafter seen as hindrances only. Greenlanders needed to change if they wanted to retain ownership of Greenland, and they would need to learn how to do so from Europeans. It was not up to the Danish authorities how Greenland would develop. Greenlander skills would defend Greenland (Petersen 19301931). Even though another author pointed out that Petersen's point of view ought to be more clearly stated, the meaning was clear: defence of ethnic-national identity had to be differentiated from defence of the Greenlandic people, and the (Danish) authorities should take care of the latter (Nielsen 1931-1932). All three articles show us how the dispute over East Greenland enhanced awareness of the need to defend Greenlandic interests in an international setting.

After the World Court verdict in The Hague, we find no report of any Greenlander challenging it. The response of course depended on attitudes toward the Danes, as usual. Indeed, there were two very differing reactions in two articles published in Avangnamiok. The critical one began with a statement that The Hague verdict was good because it awakened the Danes (i.e. it thus might force them to make a better effort in Greenland), while the rest of the article was about Greenland's riches, which were exploited however by the Danes (H.H. 1933). The positive one stressed that some Danes were not acting rightly for Greenland, but there were also many exemplary people among the Danish authorities; thus, not only did Denmark win, but so did Greenland when the verdict was announced (Dalager 1933).

\section{Conclusion}

The attitudes of Greenlanders towards explorer Fridtjof Nansen show not only their promotion of their own local "reporters," but also their homage to a Norwegian individual for his training and expertise in kayaking-and in general for his behaviour in the Nuuk area. He differed from most of the explorers that Greenlanders saw travelling around their country - and they paid him credit for it. The responses to the Danish dispute with Norway show not only a critical attitude towards the Danes whenever Greenlanders felt treated with disrespect, but also Greenlandic opinionmakers' general support for Denmark as a colonizer: they did not want Norway to take over. They would have preferred to see the monopoly abolished and the country opened up, but not until the Greenlandic population itself was sufficiently prepared.

Generally, they felt that Greenland needed to collaborate with those Danes who were dedicated to supporting the Greenlandic people, but they also wished to be drawn more and more into the decision making. This was not a new development. It might always have been the case, and certainly so in the time of Governor Rink and afterwards. It was the demand uttered in national songs and in newspapers after 1900. 
The only difference was that Norway's claims created an alternative colonizing State: a State that was sending Norwegian whalers, sealers, and land-based hunters to Greenland. Realizing that the Norwegians wanted access to the country's great hunting resources, Greenlanders differed with Danes over whether Norwegians should be offered hunting grounds in East Greenland. Meanwhile, a vehement debate began between Danes and Greenlanders over admission of Faeroese fishery boats to specific land bases in West Greenland. Greenlanders argued very much against the proposal. They did not get their way, however, despite protests. Greenlanders liked Nansen and admired him, as they would later admire the adept young hunters they met in East Greenland, but they disliked the hunting carried out by Norwegians and their claims to East Greenland or to the whole of Greenland for that matter.

The sources used in this study-newspaper articles written by Greenlanders in the 1920s and early 1930s - could be triangulated by comparing them to Danish and other European sources, newspaper articles, and official documents. For instance, concerning Nansen, it would be obvious to include his writings (e.g., Wærp 2010). However, the articles quoted here show Greenlanders exercising agency among themselves and towards the Danes, albeit within the framework of the asymmetrical power relationship between the two in colonial times. They demonstrate that Greenlanders were not passive. Neither did they act as a monolithic group, nor did Greenlanders perceive Danes that way either. They saw quite clearly the differences among the Danes in Greenland, who judged them as individuals according to their own political goals and views. The picture that emerges is quite in accordance with the theories of Nicolas Thomas (1994) about colonialism. Ditte Goldschmidt wrote about the Greenlanders and their involvement in international politics, claiming that they were hegemonized by the Danes (e.g., Goldschmidt 1987). The Greenlandic views outlined above call for a reassessment of her argument (Langgård 2011b: 306). Greenlanders did get involved in issues that seemed of interest to them. They were not empowered to make decisions that could transgress the colonial framework, but they did discuss the issues and tried to transgress the imposed limits.

I asked at the beginning of this article whether this kind of research is relevant when discussing today's political issues, e.g., when discussing whether Greenlanders and Danes should reconcile. The agency exercised by colonial Greenlanders should make today's Greenlanders rethink their positions when analysing the discourse of colonial Greenlanders and assigning them the role of the victimized. ${ }^{8}$ When a "decolonized" Greenland became part of the Danish Kingdom in 1953, many Greenlandic opinion makers thought that Greenlanders should gain equality by learning Danish and by modernizing Greenland. After a decade or so, many Greenlanders realized this was not turning out well. Mobilization for Home Rule thus started. A critical discourse developed partly based on Marxist ideology and referring to capitalism, imperialism, and oppression with no differentiation being made between

8 Negotiation, collective remembrance and forgetting, and re-writing of (ethnic-) national history are all concepts covering developments in all (ethnic-) national identities (e.g., Eriksen 2010). 
colonial times and the period after 1953. It talked of Greenlanders as being victimized, as losing their identity, as losing their language, and as standing passively aside.

Home Rule was attained in 1979. Mental decolonization took place, and for most of the population the discourse of victimization faded gradually, but not totally. In 2009, Self-Government was established. With the election of the Greenlandic parliament in 2013, it seemed as if some of the "Home Rule discourse" still appealed to those voters who chose the new political party, Partii Inuit, which focused on the language situation as if the Danes were endangering Kalaallisut. Whether Greenland does need reconciliation ${ }^{9}$ is a debate to be taken up democratically by as many people as possible in Greenland; whatever actions are needed will be asked for and taken by Greenlanders.

During 2013, some Danish politicians finally realized that Self-Government meant that from 2009 Greenlanders would be the ones to decide how to use Greenland's nonrenewable resources. Quite a few Danes in Denmark had to get used to this new situation, while Greenlanders even to this day are still realizing that the Danes are not the big problem anymore. The challenge is now to address the many new options for the Greenlandic population and to develop them satisfactorily.

Too many Greenlanders really know little about their forefathers, except for useless nostalgic slogans that will not help them as the gap between the poor and the better-off widens. They may look to their forefathers' agency and thus stop seeing both them and themselves as victims. Most of the better-off Greenlanders do not doubt their identity as Kalaallit and their agency in a global world. Greenland now has SelfGovernment and nobody is better able to handle it than Greenlanders. Likewise, only the Kalaallisut-speaking Greenlanders, i.e. the overwhelming majority, can ensure that their language will survive in today's competitive "linguistic market." I would like to see my research become a basis for future discourse on colonial times and thus for future postcolonial discourse.

\section{References}

AIDT, Leif

2008 Sunnia kalippoq, Nuuk, Ilinniusiorfik.

ANDERSON, Benedict

1983 Imagined communities: Reflection on the origin and spread of nationalism, London and New York, Verso.

\section{ANONYMOUS}

1890-1891 Aataarniat Norgemut tikittut ukioq 1889 Juuli 19 ('The harp seal sealers back in Norway July 19, 1889'), Atuagagdliutit, 1890/91: 95-96.

9 The Premier of Greenland mentioned reconciliation in her speech to the nation on January 1, 2014. 
1901-1902 Tamarlisit ('Miscellaneous'), Atuagagdliutit, 1901/02: 32.

1906-1907 Tamarlisit ('Miscellaneous'), Atuagagdliutit, 1906/07: 31-32.

BERTHELSEN, Jens

1927-1928 Nunarput illersortigu ('Let's defend our land'), Atuagagdliutit, 1927/28: $65-71$.

DALAGER, Peter S.

1933 Ulloq Apriilip tallimaat 1933 ('The day April 5, 1933'), Avangnâmiok, 1933: 68-70.

EGEDE, Lars

1926-1927 Isumaliut malillugu aniatitat ('Utterances according to thought'), Atuagagdliutit, 1926/27: 177-180.

ERIKSEN, Thomas Hylland

2010 Ethnicity and Nationalism, London and New York, Pluto Press.

GABRIELSEN, Tobias

1930 Tunuliarnilersaarut ('About a tour to East Greenland'), Avangnâmiok, 1930: 33-46.

GOLDSCHMIDT, Ditte Bentzon

1987 Danmark - moder eller koloniherre? ('Denmark - mother or colonial ruler?'), Fortid og Nutid, 3: 209-224.

H.H.

1933 Kalaallit Nunaat kalaallinut ('Greenland for Greenlanders'), Avangnâmiok, 1933: 81-83.

HAMMEKEN, V.

1889-1890 Oqalualaarutit ('Narratives'), Atuagagdliutit, 1889/90:117-122, 135-144, 147-152, 161-164.

JENSEN, Hans

1920 Tusarliussaq ('An announcement'), Avangnâmiok, 1920: 58-59.

JOAB

1887-1888 Savikasik ('A poor knife’), Atuagagdliutit, 1887/88: 143-144.

KLEIST, G.

1921 Qeqertarsuup ukiune kingulliusuni pissuseriligaanik nalunaarut ('Information about Qeqertarsuaq's situation these last years'), Avangnâmiok, 1921: 1-4. 


\section{LANGGÅRD, Karen}

1998 An examination of Greenlandic awareness of ethnicity and national selfconsciousness through texts produced by Greenlanders 1860s-1920s, Études/Inuit/Studies, 22(1): 83-107.

2010 West Greenlanders' View of East Greenlanders over Time - the discourse in Atuagagdliutit from 1861 to the First World War and in Greenlandic literature, in Karen Langgård, Flemming Nielsen, Birgit Kleist Pedersen, Kennet Pedersen and Jette Rygaard (eds), Cultural and Social Research in Greenland.. Selected Essays 1992-2010, Nuuk, Ilisimatusarfik and Forlaget Atuagkat: 175-201.

2011a Greenlandic Literature from Colonial Times to Self-Government, in Karen Langgård and Kirsten Thisted (eds), From Oral Tradition to Rap. Literatures of the Polar North, Nuuk, Ilisimatusarfik and Forlaget Atuagkat: 119-187.

2011b Ethnic-national Discourses in Greenlandic media 1861-1920, Ph.D. dissertation, University of Aalborg, Aalborg.

LINDOW, H. et al.

1924 Landsraadit oqaloqatigiissutaat ataatsimiinnermi 1924 ('The assembly's consultations during the 1924 meeting'), Avangnâmiok, 1924: 65-76.

LYNGE, Fr.

1930 Sissuernimininnguit ('Small details'), Avangnâmiok, 1930: 73-74.

LYNGE, Kristoffer

1922-1923a Nunanit allanit tusakkat (News from abroad), Atuagagdliutit, 1922/23: 4956.

1922-1923b Naqqiut (Correction), Atuagagdliutit 1922/23:168-170.

1923-1924 untitled, Atuagagdliutit, 1923/24: 135-136.

MØLLER, Lars

1889-1890 Nansenip ilaasalu Nuummi ukiisillutik angalasarneri ('The tours of Nansen while overwintering in Nuuk'), Atuagagdliutit, 1889/90: 1-7, 183-188.

1895-1896 Tunumut ajoqersuiartortitat niuertullu nunasinerat ('The settlement of those sent for missionary work and trade in East Greenland'), Atuagagdliutit, 1895/96: 49-53.

NANSEN, Fridtjof

1888-1889 Tunumit sermikkut itivinneq ('The crossing over the icecap from East Greenland'), Atuagagdliutit, 1888/89: 145-153, 162-169. 


\section{NIELSEN, Peter}

1931-1932 Inatsisit inuiaqatigiissuserlu ('The laws and the ethnic-nationality'), Atuagagdliutit, 1931/32: 105-108.

P.N.

1932 Nunanit allanit tusakkat ('News from abroad'), Avangnâmiok, 1932: 44-45.

S.P.

1932 Nunanit allanit tusakkat ('News from abroad'), Avangnâmiok, 1932: 50-53.

PETERSEN, Pavia

1930-1931 Kiinap ungalutoqarsua ('The Great Wall of China'), Atuagagdliutit, 1930/31: 153-156.

REIMER, K.

1923 "Naqqiut”-mut (“Concerning "Corrections”), Avangnâmiok, 1923: 49.

ROSENDAHL, Ph.

1930 untitled, Avangnâmiok, 1930: 74.

ROSING, Christian

1888-1889 untitled song, Atuagagdliutit, 1888/89: 160.

ROSING, Jakob

1922-1923 Iluanaarfissat annerit! ('The largest chances for economic profit!'), Atuagagdliutit, 1922/23: 161-168.

1923-1924 Iluanaarfissat annerit ('The largest chances for economic profit'), Atuagagdliutit, 1923/24: 129-135.

ROSING, P.

1920 Qallunaat ('White people'), Avangnâmiok, 1920: 33-34.

\section{SIILARSI}

1888-1889 Qallunaat ('White people'), Atuagagdliutit, 1888/89: 153-159, 170-173.

STORCH, Mathias

1911-1912 Piniarneq naammakkunnaarpat suut allat saaffigissavavut? ('If hunting declines what else shall we turn to?'), Atuagagdliutit, 1911/12: 180-182.

SØRENSEN, Axel Kjær

2007 Denmark-Greenland in the Twentieth Century, Copenhagen, Meddelelser om Grønland, Man and Society, 34. 
THOMAS, Nicolas

1994 Colonialism's Culture. Anthropology, travel and government, Cambridge, Polity Press.

TOBIASSEN, Salomon

1925-1926 Silorsuaq ('The big carcass'), Atuagagdliutit, 1925/26: 33-37.

WÆRP, Henning Howlid

2010 Fridtjof Nansen, First Crossing of Greenland (1890): Bestseller and Scientific Report, in Anka Ryall, Johan Schimanski and Henning Howlid Wærp (eds), Arctic Discourses, Newcastle, Cambridge Scholars Publishing: 43-58. 